\title{
GAMBARAN PERILAKU PETANI SAYURAN DI WILAYAH KERJA PUSKESMAS NUSA INDAH DI TINJAU DARI ASPEK KESEHATAN
}

\section{DESCRIPTION OF VEGETABLE FARMERS' BEHAVIOR IN THE WORKING AREA OF THE NUSA INDAH COMMUNITY HEALTH CENTER VIEWEDFROM HEALTH ASPECTS}

\author{
Oleh : \\ Eka Anis Apriliani1 ${ }^{1}$ Eva Oktavidiati2 ${ }^{2}$ Agus Ramon ${ }^{3}$, Nopia Wati ${ }^{4}$ \\ 1,2,3,4 Prodi Kesehatan Masyarakat Fakultas IImu Kesehatan Universitas Muhammadiyah Bengkulu
}

Email : apriliani12anis@gmail.com

\begin{abstract}
Background;The farmers' behavior in the work area of Nusa Indah community health center in eliminating Plant Pest Organisms (PPO) using pesticides. The purpose of this study is to know the description of the vegetable farmers' behavior in the work area of the Nusa Indah Community Health Center in terms of health aspects. Method;The type of this study is qualitative research. The number of informants in this study were 5 people in the Nusa Indah Community Health Center. Data collection techniques usedwere observation and interviews. From the results of the research, it was found that in eliminating plant pests organism (PPO) namely insects and fungi, farmersused pesticides, farmers do not have good knowledge about the types, dosages \& dangers of using pesticides, and knew the complete PPE that must be used while working. Farmers do not have a positive attitude towards pesticides, include the absence of a special storage area, used the type \& dosage as desired, and felt safe even though they did not wear complete PPE. The actions of farmers in using pesticides illustrate that there are still many farmers' unwise actions that can endanger health, both in the selection, storage, mixing, spraying of pesticides, using PPE, and the existence of health complaints. All farmers have implemented good PHBS starting from cleaning tools, body hygiene, and cleaning clothes. Health complaints that were felt by farmers included dizziness and nausea after they used pesticides. It is hoped that farmers have good knowledge andpositive attitudes so that the right actions are taken when using pesticides so that the action do not affect the health of farmersbecause a lack of knowledge and positive attitudes and correct actions when using pesticides.
\end{abstract}

\section{Keywords: Pesticides, Behavior, Pesticides}

\begin{abstract}
ABSTRAK
Perilaku petani di wilayah kerja Puskesmas Nusa Indah dalam pemberantasan Organisme Pengganggu Tanaman (OPT) menggunakan pestisida. Adapun tujuan dalam penelitian ini yaitu mengetahui gambaran perilaku petani di wilayah kerja Puskesmas Nusa Indah di tinjau dari aspek kesehatan. Jenis penelitian kualitatif. Informan dalam penelitian ini berjumlah 5 orang di Wilayah Kerja Puskesmas Nusa Indah. Teknik Pengumpulan data dengan observasi dan wawancara terstruktur dan dilakukan probing apabila diperlukan data yang lebih mendalam. Analisis data terdiri dari reduksi data, penyajian data dan penarikan kesimpulan dari analisis interpretasi data dan triagulasi. Dari hasil penelitian didapatkan bahwa petani dalam pengendalian organisme pengganggu tanaman (OPT) yaitu serangga dan jamur menggunakan pestisida, sedangkan pengetahuan petani belum baik akan pengenalan pestisida yang mereka pakai. Sikap petani dalam penggunaan pestisida belum baik, karena dalam penyimpanan dan penggunaan APD tidak sesuai dengan aturan yang ada. Tindakan petani dalam penggunaan pestisida mengambarkan masih banyak tindakan tidak bijaksana dari petani yang dapat membahayakan kesehatan, baik dalam pemilihan, penyimpanan, pencampuran, penyemprotan, penggunaan APD, dan adanya keluhan kesehatan. PHBS petani sudah baik mulai dari pembersihan alat, kebersihan badan, dan kebersihan pakaian. Keluhan kesehatan yang dirasakan petani berupa pusing dan mual-mual setelah mereka menggunakan pestisida. Pengetahuan yang baik dan sikap positif dapat menyebabkan tindakan yang benar saat penggunaan pestisida. Hal ini dapat mempengaruhi kesehatan petani. Kurangnya pengetahuan dan sikap positif terhadap penggunaan pestisida yang mereka gunakan dapat mempengaruhi produktivitas dari segi waktu kerja maupun kemampuan kerja.
\end{abstract}

Kata Kunci: Pestisida, Perilaku, PHBS, Keluhan Kesehatan 



\section{PENDAHULUAN}

Pestisida merupakan senyawa-senyawa kimia yang digunakan untuk membunuh Organisme Pengganggu Tanaman (OPT) yang paling banyak digunakan oleh petani di Indonesia $(95,29 \%)$ karena dianggap efektif, mudah digunakan dan secara ekonomi menguntungkan.Data dari Kementerian Pertanian sampai tahun 2016, pestisida yang terdaftar dan diijinkan di Indonesia telah mencapai 3.207 merk pestisida (Handayani dkk, 2017). Akhir-akhir ini banyak efek negatif yang ditimbulkan bagi kesehatan manusia yang berhubungan dengan penggunaan pestisida kimia yaitu, terjadinya gangguan pada kulit, gastrointestinal, neurologi, karsinogen, pernafasan, reproduksi, dan gangguan pada endrokrin (Purnomo dkk, 2019).

Menurut Lawrence Green (1980) dalam Novita dan Franciska, (2011), faktor-faktor yang mempengaruhi perilaku kesehatan adalah faktor predisposisi (predisposing factor) mencakup pengetahuan dan sikap masyarakat terhadap kesehatan, tradisi dan kepercayaan sistem nilai yang dianut, tingkat pendidikan dan tingkat sosial ekonomi. Faktor pemungkin (enabling factors) ini mencakup lingkungan tersedia dan sarana dan prasarana atau fasilitas kesehatan bagi masyarakat dan fasilitas pelayanan kesehatan. Faktor Penguat (reinforcing factors). faktor ini meliputi faktor sikap dan perilaku tokoh agama, sikap dan perilaku para petugas termasuk petugas kesehatan.

Perilaku Hidup Bersih dan Sehat (PHBS) harus mulai diterapkan dari diri sendiri. Mulai dari membersihkan badan secara teratur dan penerapan cuci tangan yang bersih, dan lainlain. Mengigat banyak orang yang lalai dalam menjaga kebersihan dan kesehatan dirinya. Padahal, kelainan itu, berdampak besar bagi dirinya sendiri, keluarga dan orang banyak (Maryuni, 2013).

Salah satu penyebab terjadinya keracunan akibat pestisida adalah petani kurang memperhatikan personal hygiene setelah melakukan penyemprotan. Dengan melakukan praktik personal hygiene petani di harapkan dapat mencegah masuknya bahan berbahaya yang terkandung dalam pestisida ke dalam tubuh. Hasil penelitian Wahyuni (2015) mendapatkan bahwa keracunan pestisida terjadi melalui kontak langsung akibat tidak menggunakan pelindung diri yang lengkap dan cara penggunaan pestisida yang tidak tepat. BPOM Provinsi Bengkulu menujukan data kasus keracunan yang di sebabkan oleh pestisida menempati salah satu 3 besar penyebab kasus keracunan, pertama di tempati oleh keracunan makanan sebanyak 104 penderita dengan penderita yang meninggal sebanyak 1 penderita, sedangkan kasus keracunan yang disebabkan oleh pestisdia sebanyak 98 pederita dengan 8 penderita yang meninggal dunia. Tingkat Provinsi, Kota Bengkulu menempati posisi kedua setelah Rejang Lebong dalam kasus keracunan pestisida yaitu sebanyak 19 penderita (Syafrudin dkk, 2018).

Data register menunjukan angka kejadian ISPA di Puskesmas Nusa Indah tahun 2020 dari bulan Januari-Mei sebesar 1.080 orang, sedangkan angka gangguan kulit yang terdapat di Puskesmas Nusa Indah sebesar 720 orang pada tahun 2020 dari bulan JanuariMei.

Survei awal pada petani sayuran organik yang berada di Wilayah Kerja Puskesmas Nusa Indah Kota Bengkulu menunjukan adanya indikasi menggunakan pestisida. Hal ini dapat dilihat dari hasil sayuran yang ada, tidak ada tanda keberadaan serangga yang menyerang tanaman seperti daun yang berlubang karena serangga (hama).

Berdasarkan uraian latar belakang di atas, maka penulis tertarik untuk melakukan penelitian dengan judul "Gambaran Perilaku Petani Sayuran Di Wilayah Puskesmas Nusa Indah ditinjau Dari Aspek Kesehatan". Tujuan penelitian ini untuk mengetahui gambaran perilaku petani sayuran di Wilayah Kerja Puskesmas Nusa Indah ditinjau dari aspek kesehatan.

\section{METODE}

Jenis penelitian yang digunakan dalam penelitian ini adalah deskriptif kualitatif. Teknik pengumpulan data dilakukan melalui wawancara menggunakan pedoman wawancara, observasi menggunakan lembar observasi. Sumber informasi dalam penelitian 
ini berjumlah 7 orang yaitu 1 orang Petugas Puskesmas Nusa Indah Kota Bengkulu, dan 1 orang Penyuluh Pertanian di Wilayah Kerja Puskesmas Nusa Indah Kota Bengkulu, sebagai triangulasi sumber, 5 orang petani sayuran di Wilayah Kerja Puskesmas Nusa Indah Kota Bengkulu sebagai informan.Teknik analisis mencakup transkrip hasil wawancara, reduksi data, analisis interpretasi data dan triangulasi sumber sehingga didapat kesimpulan.
Penelitian ini dilaksanakan di lahan petani sayuran yang berada di Wilayah Kerja Puskesmas Nusa Indah Kota Bengkulu. Waktu pelaksanaan penelitian dari Agustus hingga September 2020.

\section{HASIL PENELITIAN}

Karakter Informan dan triangulasi sumber dalam penelitian disajikan pada Tabel 1 dan Tabel 2.

Tabel 1

Karakteristik Data Responden

\begin{tabular}{cccc}
\hline Informan & Umur & Jenis Kelamin & Keterangan \\
\hline Informan 1 & 45 & Perempuan & Petani 1 \\
Informan 2 & 47 & Laki-laki & Petani 2 \\
Informan 3 & 40 & Laki-laki & Petani 3 \\
Informan 4 & 43 & Perempuan & Petani 4 \\
Informan 5 & 41 & Laki-laki & Petani 5 \\
\hline
\end{tabular}

Sumber : Data Primer, (2020)

Tabel 2

Karakteristik Triangulasi

\begin{tabular}{cccc}
\hline Nama & Umur & Jenis Kelamin & Keterangan \\
\hline Triangulasi 1 & 35 & Perempuan & Petugas Puskesmas \\
Triangulasi 2 & 38 & Perempuan & Penyuluh Pertanian \\
\hline
\end{tabular}

Sumber : Data Primer, (2020)

Dari beberapa masyarakat yang di wawancarai di dapatkan 4 petani menggunakan pestisida dalam pemberantasan organisme pengganggu tanaman (OPT) seperti serangga dan penyakit jamur pada tanaman sayuran, kemudian diketahui ada beberapa petani yang memiliki pengetahuan kurang baik dalam penggunaan pestisida, kemudian sikap petani cukup baik dalam penggunaan pestisida, untuk tindakan petani kurang baik dalam penggunaan pestisida, PHBS sudah baik, ada 2 petani yang mengalami keluhan kesehatan namun hanya 1 petani yang mendatangi Puskesmas jika merasakan pusing dan mual-mual.

\section{Pengetahuan}

Pengetahuan sangat diperlukan dalam penggunaan pestisida, karena jika petani tidak memiliki pengetahuan tentang penggunaan pestisida yang baik justru akan menimbulkan dampak yang buruk baik lingkungan, konsumen, dan petani itu sendiri. Hal ini di dukung oleh (Panut, 2008) Penggunaan pestisida pertanian berpotensi menimbulkan dampak negatif bagi pengguna, konsumen, lingkungan, serta dampak sosial ekonomi. Oleh karena itu, penggunaan pestisida harus dilakukan secara hati-hati. Tujuan penggunaan pestisida harus ditekankan untuk menurunkan populasi hama, menghentikan serangan penyakit, dan mengendalikan gulma agar keberadaannya tidak menyebabkan kerugian ekonomis atau bisa menekan kehilangan hasil. 
Pada umumnya penggunaan pestisida diaplikasikan dengan cara disemprotkan. Namun demikian, tidak semua jenis OPT dapat di kendalikan dengan cara disemprot. Pada jenis OPT tertentu dan tanaman tertentu, aplikasi pestisida dapat dilakukan dengan cara penyiraman, perendaman, penaburan, pengembusan, pengolesan, dll. Informasi tersebut dapat diperoleh dari brosur atau label kemasan pestisida (Tonny dkk, 2015).

Dari hasil wawancara yang
dilakukan peneliti bertempat di perkebunan sayuran di wilayah kerja Puskesmas Nusa Indah Kota Bengkulu peneliti mendapatkan data-data yang peneliti perlukan dari petani. Hasil wawancara mengenai pengetahuan petani tentang kegunaan pestisida dan jenis pestisida yang mereka gunakan, hal ini peneliti simpulkan dari wawancara yang telah dilakukan bersama informan 1 , informan 2, informan 3, informan 4 sebagai berikut:

"kalau kami pakai semprotnya gak yang racun nakutin, racun kecil-kecil racun apa itu, kalau kami pestisida itu lah"(Wawancara terhadap informan 1, 29 Agustus 2020)

"Ya pakai pestisida itu lah, pakai apa lagi"(Wawancara terhadap informan 2, 29 Agustus 2020)

"Iya pakai, pakai semprot, tergantung hama biasanya"(Wawancara terhadap informan 3, 30 Agustus 2020)

"obat jamur itu lah, ya pestisida" (Wawancara terhadap informan 4, 30 Agustus 2020)

Hasil wawancara tentang pengetahuan penyimpanan pestisida yang aman dan tidak berbahaya, hal ini peneliti simpulkan dari wawancara yang telah dilakukan bersama informan 1, informan 2, informan 3, informan 4 sebagai berikut:

"kalau nyimpannya yang penting jauh dari anak-anak. di dapur nyimpannya di pojok
ruangan"(Wawancara terhadap informan 1, 29 Agustus 2020)

"nyimpannya di ember di bawah meja dapur"(Wawancara terhadap informan 2, 29 Agustus 2020)

"di kebun ini lah nyimpan pestisidanya saya taruh aja di pojokkan itu" (Wawancara terhadap informan 3, 30 Agustus 2020)

"ya di simpan di dapur, kalau tempatnya di ember kadang di kantong plastik juga" (Wawancara terhadap informan 4, 30 Agustus 2020)

Hasil wawancara tentang pengetahuan pedoman pencampuran pestisida aman sesuai dengan dosis yang sesuai anjuran, hal ini peneliti simpulkan dari wawancara yang telah dilakukan bersama informan 1, informan 2, informan 3 , informan 4 sebagai berikut:

"takarannya, pakai sendok kalau saya. satu tangki tu biasanya 2 sendok."(Wawancara terhadap informan 1, 29 Agustus 2020)

"Ya baca kemasanya dulu, kalau mau ngunakanya. kan udah ada dosisnya berapa yang harus digunain dalam luas lahan berapa"(Wawancara terhadap informan 2, 29 Agustus 2020)

"gak saya baca, Cuma pakai tutup botol itu kalau mau ngunainnya"(Wawancara terhadap informan 3, 30 Agustus 2020)

"saya baca dulu sih biasanya" (Wawancara terhadap informan 4, 30 Agustus 2020)

Hasil wawancara tentang pengetahuan pencampuran pestisida yang aman dilakukan di luar rumah atau di tempat terbuka, hal ini peneliti simpulkan dari wawancara yang telah dilakukan bersama informan 1 , informan 2, informan 3, informan 4 sebagai berikut: "kalau mau penyemprotan ya di rumah nyampurkannya, kalau di kebun malas bawanya"(Wawancara terhadap informan 1, 29 Agustus 2020)

"Ya kadang di kebun, tinggal mau nyemprot seberapa kalau banyak baru saya bawa ke kebun, kalau Cuma 1 
tangki mah di rumah aja nyampurinya" (Wawancara terhadap informan 2, 29 Agustus 2020)

"Iya kan pestisidanya ada di kebun, jadi di kebun itulah nyampurkannya"

(Wawancara terhadap informan 3, 30 Agustus 2020)

" oh kalau ngunain pestisidanya saya langsung taruh di tangki biar enak gak bawa-bawa pestisidanya ke kebun." (Wawancara terhadap informan 4, 30 Agustus 2020)

\section{Sikap}

Hasil wawancara mengenai sikap petani tentang pestisida yang mereka gunakan sudah terdaftar, hal ini peneliti simpulkan dari wawancara yang telah dilakukan bersama informan 1 , informan 2 , informan 3, informan 4 sebagai berikut: "ya belinya di toko tanaman obat"(Wawancara terhadap informan 1, 29 Agustus 2020)

"di toko dekat sini lah"(Wawancara terhadap informan 2, 29 Agustus 2020) "lya yang di toko"(Wawancara terhadap informan 3, 30 Agustus 2020)

"ya di toko sana dekat pasar"(Wawancara terhadap informan 4, 30 Agustus 2020)

Hasil wawancara mengenai sikap petani selama penggunaan pestisida tidak merokok, makan, dan minum, hal ini peneliti simpulkan dari wawancara yang telah dilakukan bersama informan 1, informan 2, informan 3, informan 4 sebagai berikut:

"ya gak, Cuma nyemprot aja"(Wawancara terhadap informan 1, 29 Agustus 2020)

"Ya gak lah kan lagi nyemprot" (Wawancara terhadap informan 2, 29 Agustus 2020)

"gak ada, ya nyemprot aja "(Wawancara terhadap informan 3, 30 Agustus 2020)

"ya engak" (Wawancara terhadap informan 4, 30 Agustus 2020)

Hasil wawancara mengenai sikap petani menggunakan APD yang lengkap akan, hal ini peneliti simpulkan dari wawancara yang telah dilakukan bersama informan 1, informan 2, informan 3, informan 4 sebagai berikut:

"ya gini kalau pakai begini aja, maskernya pakai, pelindung mata yang gimana oh kayak kacamata gak pakai, kalau topi pakai, sepatu boot juga, kalau sarung tangan gak pakai saya"(Wawancara terhadap informan 1, 29 Agustus 2020) "masker ya pakai, topi juga pakai, kalau sarung tangan gak pakai, sepatu boot pakai"(Wawancara terhadap informan 2, 29 Agustus 2020)

"pakaianya ya gini aja, masker gak pakai, topi pakai, sarung tangan gak pakai saya. sepatu boot juga gak"(Wawancara terhadap informan 3, 30 Agustus 2020)

"oh ya pakai masker lah, sepatu boot juga, apa kalau sarung tangan gak pakai, topi juga pakai panas kan soalnya"(Wawancara terhadap informan 4, 30 Agustus 2020)

Hasil wawancara mengenai sikap petani dalam PHBS selama penggunaan pestisida, hal ini peneliti simpulkan dari wawancara yang telah dilakukan bersama informan 1, informan 2, informan 3, informan 4 sebagai berikut:

"kalau abis dari kebun ya saya langsung saya bersiihkan semua, mandi, cuci baju juga"(Wawancara terhadap informan 1, 29 Agustus 2020)

"Ya mandi lah soalnya gak nyaman, bajunya ya saya cuci langsung"(Wawancara terhadap informan 2, 29 Agustus 2020)

"ya mandi, ya saya cuci sambil mandi" (Wawancara terhadap informan 3, 30 Agustus 2020)

"ya jelas abis itu mandi, bajunya sekalian dicuci"(Wawancara terhadap informan 4, 30 Agustus 2020)

\section{Tindakan}

Hasil wawancara mengenai tindakan petani dalam pemilihan pestisida saat penggunaan pestisida, hal ini peneliti simpulkan dari wawancara yang telah dilakukan bersama informan 1 , informan 2 , informan 3 , informan 4 sebagai berikut: 
"kalau kami pakai semprotnya gak yang racun nakutin, racun kecil-kecil racun apa itu, kalau kami pestisida itu lah" (Wawancara terhadap informan 1, 29 Agustus 2020)

"ya pakai pestisida pakai apa lagi" (Wawancara terhadap informan 2, 29 Agustus 2020)

"Ya tergantung hamanya apa, kalau daunya jamur ya pakai obat jamur kalau ada hama serangga ya saya kasih obat serangga"(Wawancara terhadap informan 3, 30 Agustus 2020)

"obat jamur itu lah, ya pestisida" (Wawancara terhadap informan 4, 30 Agustus 2020)

Hasil wawancara mengenai tindakan petani dalam penyimpanan pestisida saat penggunaan pestisida, hal ini peneliti simpulkan dari wawancara yang telah dilakukan bersama informan 1 , informan 2, informan 3, informan 4 sebagai berikut:

"ya kalau nyimpannya digantung di paku radak sudut, ada yang di ember juga yang penting jauh dari anak-anak" (Wawancara terhadap informan 1, 29 Agustus 2020)

"kalau nyimpan pestisida diember, dibawah meja di dapur" (Wawancara terhadap informan 2, 29 Agustus 2020)

"simpan dalam ember, gak di rumah di kebun inilah" (Wawancara terhadap informan 3, 30 Agustus 2020)

"itu nyimpannya di tempat agak aman, iyo di ember digantung" (Wawancara terhadap informan 4, 30 Agustus 2020)

Hasil wawancara mengenai tindakan petani dalam pencampuran pestisida saat penggunaan pestisida, hal ini peneliti simpulkan dari wawancara yang telah dilakukan bersama informan 1 , informan 2, informan 3, informan 4 sebagai berikut:

"kalau biasnya setangki tu dua sendok makan gak pula banyak-banyak" (Wawancara terhadap informan 1, 29 Agustus 2020)
"Ya sesuai di kemasanya itu berapa bagusnya biar hamnya cepet hilang" (Wawancara terhadap informan 2, 29 Agustus 2020)

"pakai tutup botol, gak pernah si saya baca"(Wawancara terhadap informan 3, 30 Agustus 2020)

"saya liat kemasanya dulu baru di gunain" (Wawancara terhadap informan 4, 30 Agustus 2020)

Hasil wawancara mengenai tindakan petani dalam penyemprotan pestisida saat penggunaan pestisida, hal ini peneliti simpulkan dari wawancara yang telah dilakukan bersama informan 1 , informan 2, informan 3, informan 4 sebagai berikut:

"ya kalau kami sih biasannya pagi nyemprotnya, ya pakai masker waktu nyemprotnya " (Wawancara terhadap informan 1, 29 Agustus 2020)

"sebisanya saya kadang pagi kadang sore, kalau itu topi saya pakai masker juga abis itu sepatu juga" (Wawancara terhadap informan 2, 29 Agustus 2020)

"biasanya sore hari, saya paginya sampai sore kerja, gak pakai ya begini aja kadang pakai masker yang lain gak pernah"(Wawancara terhadap informan 3, 30 Agustus 2020)

"pagi, sore juga pernah, ya pakai semua oh kalau sarung tangan gak pakai" (Wawancara terhadap informan 4, 30 Agustus 2020)

\section{PHBS Petani}

Hasil wawancara mengenai PHBS petani dalam penggunaan pestisida, hal ini peneliti simpulkan dari wawancara yang telah dilakukan bersama informan 1 , informan 2, informan 3, informan 4 sebagai berikut:

"ya dibersihkan semua ya seluruhnya dicuci, baju dicuci, rambut di keramasi" (Wawancara terhadap informan 1, 29 Agustus 2020)

"iyo pasti di bersihkan, iya bajunya dicuci, mandi sambil keramas juga" (Wawancara terhadap informan 2, 29 Agustus 2020) 
"ya di bersihkan lah, ya mandi lah, iya ganti abis tu di cuci" (Wawancara terhadap informan 3, 30 Agustus 2020) "ya di bersihkan di rumah, ya mandi bajunya dicuci" (Wawancara terhadap informan 4, 30 Agustus 2020)

\section{Keluhan Kesehatan}

Hasil wawancara mengenai Keluhan kesehatan yang pernah dialami oleh petani sayuran di Wilayah Kerja Puskesmas Nusa Indah Kota Bengkulu. Hal ini dibuktikan dari jawaban informan 1 , informan 2 sebagai berikut:

"ya waktu nyemprotkan kebauan, itukan rasanya nak mual-mual, pusing, nyemprotnya cepatlah kita nyemprotnya waktunya, biar agak cepatkan cepat selesai terus mandi" (Wawancara terhadap informan 1, 29 Agustus 2020)

"iyo pernah pusing " (Wawancara terhadap informan 2, 29 Agustus 2020)

Selanjutnya hasil wawancara tentang bagaimana petani setelah merasakan keluhan kesehatan, apakah langsung mendatangi puskesmas. Hal ini dibuktikan dari jawaban informan 1 informan 2 sebagai berikut:

"kalau kami ke puskesmas, gak pernah kalau di urus di rumah, datang ke puskesmas tu lah" (Wawancara terhadap informan 1, 29 Agustus 2020)

"idak pergi ke Puskesmas, minum air kelapotrus tidur" (Wawancara terhadap informan 2, 29 Agustus 2020)

Dari hasil pertanyaan tentang bagaimana petani setelah mengalami keluhan kesehatan akibat penyemprotan oleh informan 1, dan informan 2, di dukung oleh pernyataan triangulasi 1 sebagai berikut:

"oh pernah ada yang datang ke puskesmas, tapi idak banyak keluhannya biasanya pusing sama pandangan kunang-kunang sama mual-mual" (Wawancara terhadap triangulasi 1, , 01 September 2020)

\section{PEMBAHASAN}

\section{Pengetahuan Petani Sayuran di Wilayah Kerja Puskesmas Nusa Indah.}

Pengetahuan adalah hasil dari tahu dan ini terjadi setelah seseorang melakukan penginderaan terhadap suatu objek. Penginderaan terjadi melalui pancaindera manusia yakni, indra pendengaran, penglihatan, penciuman, perasaan dan perabaan. Sebagai pengetahuan manusia didapat melalui mata dan telinga (Notoatmodjo, 2012).

Berdasarkan hasil wawancara terhadap 5 orang petani, petani mengetahui kegunaan pestisida sebanyak 5 orang petani, namun petani di wilayah kerja Puskesmas Nusa indah Kota Bengkulu tidak mengetahui perbedaan antara pestisida dengan kelompok-kelompok seperti insektisida, fungisida, herbisida, dan sebagainya. Hal ini tidak sesuai dengan Peraturan Pemerintah RI nomor 6 tahun 1995 yang menyatakan pestisida yang digunakan harus disesuaikan dengan jenis organisme pengganggu tanaman (tepat jenis). Pengetahuan mengenai kegunaan kelompok-kelompok pestisida sangat penting dalam pemilihan pestisida yang akan digunakan oleh petani. Hal ini dimaksudkan petani memilih pestisida berdasarkan organisme pengganggu tanaman (OPT) yang ada di lahannya.

Petani mengetahui bahwa penggunaan pestisida dapat menyebabkan keluhan kesehatan. setiap jenis pestisida memiliki risiko bahaya bagi kesehatan manusia, hewan, dan lingkungan hidup meskipun tidak semua jenis pestisida memiliki risiko yang sama (Wudianto, 2001). Oleh karena itu petani harus bijak dalam penggunaan pestisida.

Petani mengetahui penyimpanan pestisida yang aman harus jauh dari jangkauan anak-anak sebanyak 4 orang, dan mengetahui penyimpanan sisa pestisida yang aman dalam wadah atau pembungkus asli yang tertutup rapat, tidak bocor, dan tidak terkena sinar matahari langsung sebanyak 3 orang. Satu petani menyimpan pestisida di area perkebunan dan hanya diletakkan di pinggiran area kebun. Menurut teori (Sudarmo, 1991) yang menyatakan bahwa 
penyimpanan pestisida pada ruangan terkunci yang memiliki ventilasi baik, tidak terkena sinar matahari secara langsung, dan merupakan ruangan yang tidak bocor karena air hujan.

Petani yang mengetahui pedoman pencampuran pestisida aman sesuai dengan dosis yang sesuai anjuran sebanyak 2 orang petani, namun 2 petani lain tidak membaca label kemasan saat menggunakan pestisida mereka mengatakan dosis yang mereka gunakan hanya menggunakan tutup botol dan sendok untuk dosis penggunaan pestisida, hal itu dilakukan sesuai dosis keinginan petani itu sendiri. Hasil ini berbeda dengan Retno, (2019) yang menjelaskan bahwa dosis pestisida merupakan takaran pestisida yang digunakan oleh petani. Dosis pestisida yang digunakan setiap kali melakukan penyemprotan dapat mempengaruhi besar atau kecilnya dampak yang ditimbulkan. Kebiasaan penggunaan pestisida yang tidak memperhatikan anjuran pemakaian yang sudah tertera pada label, dapat menimbulkan resistensi pada hama dan dapat memperbesarkan resiko gangguan kesehatan yang ditimbulkan baik jangka pendek maupun jangka panjang.

Penggunaan pestisida yang tidak sesuai dengan dosis atau takaran yang tertera dalam kemasan ataupun label pestisida dapat mempengaruhi efikasi pestisida dan meningkatkan residu pada hasil panen yang membahayakan bagi konsumen (Tonny dkk, 2015).

Saat pencampuran pestisida 2 petani mengetahui pencampuran pestisida yang aman dilakukan di luar rumah atau di tempat terbuka, Namun 2 orang petani mengatakan pencampuran dilakukan di dalam rumah dengan alasan sedikitnya luas lahan yang akan di aplikasikan dengan pestisida, sehingga petani tidak perlu membawa tempat pestisida ke kebun. Hal ini bertentangan dengan teori yang menyatakan bahwa pencampuran pestisida sebaiknya dilakukan di tempat yang memiliki sirkulasi udara yang baik karena di tempat tertutup pestisida memiliki daya racun yang lebih tinggi sehingga dapat mengakibatkan keracunan melalui pernapasan (Panut, 2008)

Keseluruhan pengetahuan petani belum baik dalam pengenalan pestisida yang mereka pakai. Pengetahuan seseorang dapat membentuk suatu proporsi atau sikap terhadap objek, pengetahuan dapat menjadi suatu sikap bila pengetahuan dikembangkan menjadi domain tertinggi hingga dapat dilakukan penilaian.

Pengetahuan petani yang belum baik ini disebabkan oleh penyuluhan tentang informasi penggunaan pestisida yang baik dan benar telah diberikan kepada kelompok pertanian secara tidak merata sehingga menyebabkan pengetahuan petani masih rendah dan mengabaikan aspek kesehatan dan keselamatan kerja. Hal ini sejalan dengan penelitian (Okkoffo dkk, 2016) yang menyatakan bahwa pengetahuan petani secara signifikan $(P<0,01) \quad$ akan mempengaruhi keputusan petani dalam penggunaan APD secara lengkap dengan upaya meningkatkan pengetahuan tentang efek bahaya dari pestisida yang baik akan memotivasi untuk menggunakan APD saat mengaplikasikan pestisida.

\section{Sikap Petani Sayuran di Wilayah Kerja Puskesmas Nusa Indah.}

Sikap merupakan reaksi atau respon yang masih tertutup dari seseorang terhadap suatu objek. Sikap secara nyata menunjukkan konotasi adanya kesesuaian reaksi terhadap objek tertentu yang dalam kehidupan seharihari merupakan reaksi bersifat emosional terhadap objek sosial (Notoatmodjo, 2012)

Sikap petani menunjukkan petani yang setuju dengan penggunaan yang telah terdaftar dan di izinkan dinas pertanian sebanyak 4 petani. hal ini sesuai dengan (Kementerian RI, 2016) yaitu membeli pestisida yang terdaftar dan memiliki Material Safety Data Sheet (MSDS) atau lembar data keselamatan. 2 orang petani tidak mengikuti pedoman pencampuran pestisida sesuai dosis takaran/ anjuran. Hal ini berbanding terbalik dengan penelitian (Wahyuni, 2010) sikap tepat penggunaan dosis sangat dibutuhkan oleh petani karena penggunaan 
dosis yang berlebihan justru akan menyebabkan terganggunya ekosistem dan kesehatan manusia.

Para petani selama penggunaan pestisida tidak merokok, makan, dan minum. Pada penelitian Raenhard, (2018) menjelaskan faktor seperti merokok saat menyemprot pestisida juga dapat mengakibatkan tingginya risiko keracunan pestisida pada petani karena kontaminasi pestisida pada tangan dan menimbulkan gejala keracunan setelah melakukan penyemprotan pestisida sehingga kadar enzim cholinesterase dalam darah menurun.

Kemudian para petani tidak setuju bahwa menggunakan APD yang lengkap akan mencegah pestisida masuk dalam tubuh dan menyebabkan keluhan kesehatan. Deptan, (2011) menyatakan bahwa APD lengkap yang dibutuhkan seorang petani selama melakukan penggunaan pestisida adalah sarung tangan, baju lengan panjang, celana panjang, topi, sepatu boot, da masker bersih, dilihat dari persentase sikap yang benar dari petani maka dapat disimpulkan bahwa sikap petani mengenai penggunaan pestisida belum baik, karena petani masih menyimpan pestisida tidak di tempat yang tertutup walaupun mereka tau pestisida itu berbahaya, kemudian masih ada petani yang tidak mengikuti pedoman pencampuran pestisida sesuai dosis pada label kemasan pestisida, selanjutnya seluruh petani tidak menggunakan APD dengan lengkap saat penggunaan pestisida. Sikap yang baik merupakan salah satu komponen penting dalam pembentukan tindakan yang baik.

Seluruh petani segera mandi setelah melakukan penyemprotan. Penelitian Raenhard, (2018) menjelaskan dalam mengurangi risiko gejala keracunan akut perlu dilakukannya langkah dengan baik dan lengkap, seperti mulai dari mencuci tangan dengan sabun dan air mengalir pada saat sebelum dan sesudah meracik, menggunakan air yang bersih, mandi serta mengganti pakaian.

Selain itu seluruh petani segera mencuci pakaian yang digunakan saat penggunaan pestisida. Pada penelitian
Raenhard, (2018) menjelaskan Tidak mencuci pakaikan kerja dapat memperbesar peluang terkontaminasinya pestisida kedalam tubuh melalui penyerapan pada kulit, dan faktor seperti merokok saat menyemprot pestisida juga dapat mengakibatkan tingginya risiko keracunan pestisida pada petani karena kontaminasi pestisida pada tangan dan menimbulkan gejala keracunan setelah melakukan penyemprotan pestisida sehingga kadar enzim cholinesterase dalam darah menurun.

Keseluruhan sikap petani dalam penggunaan pestisida belum baik, karena petani menyimpan pestisida tidak di ruangan khusus melainkan menyimpan di area dapur selain itu satu petani menyimpan pestisida di area kebun yang langsung terpapar sinar matahari, selanjutnya sikap petani dalam penetapan dosis penggunaan yang seharusnya menyesuaikan dosis pada label kemasan namun mereka menggunakan dosis dengan keinginan mereka sendiri, kemudian sikap petani dalam penggunaan APD seluruh petan tidak menggunakan APD lengkap saat penggunaan pestisida.

\section{Tindakan Petani Sayuran di Wilayah Kerja Puskesmas Nusa Indah.}

Suatu sikap yang belum otomatis terwujud dalam suatu tindakan (overt behavior) mewujudkan sikap menjadi suatu perbuatan nyata diperlukan faktor pendukung seperti fasilitas serta dukungan dari berbagai pihak (Notoatmodjo, 2012). Tindakan petani menggunakan pestisida dinilai dari pemilihan, penyimpanan, penyemprotan, dan pencampuran pestisida uang dilakukan oleh petani di wilayah kerja Puskesmas Nusa Indah Kota Bengkulu.

Hasil wawancara menunjukkan pemilihan pestisida oleh petani di lihat dari petani yang menggunakan pestisida sesuai Peraturan Menteri Pertanian No 48 Tahun 2009 yaitu pestisida yang terdaftar, diizinkan yaitu sebanyak 4 orang petani. Pada umumnya petani menggunakan merek sesuai dengan pengalaman mereka. Sementara penggunaan racun yang tidak tepat tentu dapat mengakibatkan hal-hal yang tidak diinginkan, seperti jasad pengganggu yang 
akan di berantas tidak mati karena salah jenis pestisida yang digunakan (Panut, 2008). Pemilihan pestisida yang baik juga dapat dilakukan dengan menyesuaikan jenis pestisida dan hama target yang dapat dilihat pada label kemasan (Sudarmo, 1991).

Penyimpanan pestisida oleh petani dilihat dari hasil wawancara petani yang menyimpan pestisida di dalam rumah sebanyak 3 orang petani, sedangkan 1 orang petani menyimpan pestisida di area perkebunan. Berdasarkan hasil observasi petani menyimpan pestisida di dalam rumah di area dapur di letakkan di bawah meja, sedangkan 1 petani menyimpan di area perkebunan agar lebih mudah saat akan menggunakan. Tempat penyimpanan pestisida berupa dan di letakkan dibawah meja di area dapur. Penyimpanan pestisida yang dapat mengurangi kemungkinan petani mengalami kecelakaan akibat kerja akibat kesalahan penggunaan pestisida (Panut, 2008). Misalnya dengan menyimpan pada label kemasan maka petani bisa membaca petunjuk penggunaan pestisida setiap kali hendak menggunakannya sehingga tidak terjadi kesalahan yang dapat menciderai petani. Tindakan petani tidak sesuai dengan Sudarmo, (1991) yang menyatakan bahwa penyimpanan pestisida pada ruangan terkunci yang memiliki ventilasi baik, tidak terkena sinar matahari secara langsung, dan merupakan ruangan yang tidak bocor karena air hujan. Hal ini untuk menghindari penurunan kemanjuran pestisida. Selain itu Kementrian RI, (2016) menjelaskan pestisida harus disimpan di tempat kering, dingin, dan gelap. Hindari tempat dengan temperatur suhu tinggi, selalu menyimpan pestisida pada kemasan asli dengan melampirkan label, ikuti petunjuk penyimpanan yang terdapat pada label kemasan, jangan pernah menyimpan makanan dan pestisida bersamaan, tidak menaruh wadah pestisida di tempat yang terkena matahari langsung.

Pencampuran pestisida oleh petani dilihat dari hasil wawancara petani yang mencampurkan pestisida sesuai dosis anjuran petunjuk penggunaan pestisida yang benar sebanyak 2 orang petani, sedangkan 2 orang petani tidak membaca dosis petunjuk penggunaan pada kemasan pada saat akan menggunakan pestisida. Petani cenderung menggunakan pestisida dengan dosis yang mereka inginkan sendiri. Hal ini tidak sesuai dengan teori yang dinyatakan oleh (Sudarmo, 1991) bahwa pencampuran dalam ketepatan penentuan dosis merupakan hal teknis yang perlu di perhatikan dalam penggunaan pestisida. Selanjutnya Sukandarrumidi dkk, (2017) menyatakan dalam mencampurkan pestisida sesuaikan dengan takaran yang dianjurkan, dan tidak diperbolehkan mencampur pestisida lebih dari satu jenis kecuali dianjurkan. Kementerian RI, (2016) menyatakan saat akan menggunakan pestisida sebaiknya membaca petunjuk dosis penggunaan, saat melakukan pencampuran dilakukan ditempat yang terbuka atau di ruangan dengan ventilasi yang cukup, hindari kebocoran dan tumpahan, jangan pernah mencampur pestisida tanpa menggunakan sarung tangan sesuai standar yang di sarankan, setelah mencampur pestisida cuci tangan menggunakan sabun. Penggunaan dosis yang ditetapkan juga dapat menyebabkan hama menjadi resisten terhadap pestisida (Panut, 2008). Penggunaan pestisida yang tidak sesuai dengan dosis atau takaran yang tertera dalam kemasan ataupun label pestisida dapat mempengaruhi efikasi pestisida dan meningkatkan residu pada hasil panen yang membahayakan bagi konsumen (Tonny dkk, 2015)

Penyemprotan pestisida oleh petani dilakukan saat usia tanaman berumur 5 hari. Tindakan petani dalam penggunaan pestisida dapat dilihat dari hasil wawancara, selama penggunaan pestisida seluruh petani tidak merokok, makan, dan minum. Hal ini sesuai dengan Kementerian RI, (2016) yang menyatakan saat menggunakan pestisida petani tidak diperbolehkan untuk makan, minum, maupun merokok. Dalam penggunaan APD seluruh petani tidak ada yang menggunakan APD dengan lengkap. APD yang paling banyak digunakan petani 
ialah sepatu boot, masker dan topi. Hal ini menunjukan kesadaran petani dalam menggunakan APD masih rendah, hal ini di dukung oleh kondisi petani yang tidak nyaman menggunakan APD saat kerja. Sementara Kementerian RI, (2016) menyatakan bahwa pengguna dapat mengurangi paparan dan risiko kecelakaan akibat penggunaan pestisida jika menggunakan APD meliputi pelindung kepala, pelindung mata dan wajah, alat pelindung pernapasan, sarung tangan, pakaian pelindung, sepatu boot yang terbuat dari karet, sarung tangan harus bisa melindungi, nyaman digunakan dan cukup fleksibel saat memegang kemasan pestisida, sarung tangan dan sepatu harus dicuci setelah pemakaian untuk menghindari kontaminasi, pakaian yang digunakan harus tahan terhadap pestisida, pakaian dicuci terpisah dengan pakaian sehari-hari, Alat pelindung diri harus disimpan dalam keadaan bersih, kering dan ruang yang memiliki ventilasi yang baik, menggunakan masker/ respirator sesuai standar. Istianah dan Yuniastuti, (2017) dalam penelitian mendapatkan sebagian besar petani tidak menggunakan APD secara lengkap yaitu sebanyak 70 petani, petani yang menggunakan APD tidak lengkap sebagian besar mengalami keracunan akibat pestisida sebanyak 51 orang $(72,9 \%)$, kemudian petani yang menggunakan APD secara lengkap 16 petani dan yang mengalami keracunan hanya sebanyak 4 orang (25\%). dalam penelitian (Herdinanti, 2018) diperoleh nilai p-value 0,028 ( $<0,05$ ), maka dapat disimpulkan bahwa ada perbedaan proporsi tindakan penyemprotan dengan gejala keracunan pestisida. Sehingga dapat disimpulkan ada hubungan yang bermakna antara tindakan penyemprotan dengan gejala keracunan pestisida pada petani nanas di Kecamatan Sungai Gelam Kabupaten Muaro Jambi. Penelitian Welkriana dan Khasanah (2020) menunjukkan bahwa petani di Desa Keban Agung Kabupaten Kepahiang Provinsi Bengkulu, $74 \%$ memiliki jumlah monosit normal dan $26 \%$ abnormal dengan adanya penggunaan APD ketika melakukan penyemprotan pestisida.

Keseluruhan tindakan petani pada penggunaan pestisida menggambarkan masih banyak tindakan tidak bijaksana dari petani yang dapat membahayakan kesehatan, baik dalam pemilihan, penyimpanan, pencampuran, penyemprotan, penggunaan APD, keluhan kesehatan. Pada umumnya petani belum menyadari pentingnya mengikuti SOP (Standart Operasional Personal) penggunaan pestisida yang merupakan racun yang dapat menyebabkan gangguan kesehatan bila tidak ditangani dengan benar. Terjadinya gangguan kesehatan akibat penumpukan pestisida dalam tubuh mengakibatkan kerugian bagi petani sendiri. Hal ini akan membuat petani kehilangan produktivitas bagi dari segi waktu kerja maupun kemampuan kerja

\section{PHBS Petani Sayuran di Wilayah Kerja Puskesmas Nusa Indah.}

PHBS adalah semua perilaku kesehatan yang dilakukan karena kesadaran pribadi sehingga keluarga dan seluruh anggotanya mampu menolong diri sendiri pada bidang kesehatan serta memiliki peran aktif dalam aktivitas masyarakat.

PHBS di tempat kerja adalah kegiatan untuk memberdayakan para pekerja agar tahu dan mau melakukan Perilaku Hidup Bersih dan Sehat dan berperan dalam menciptakan tempat kerja yang sehat, manfaat PHBS di tempat kerja yaitu pekerja mampu meningkatkan produktifitas kerja dan meningkatkan citra tempat kerja yang positif.

PHBS petani atau personal hygiene yang dimaksud merupakan kebersihan tangan dan kuku, kebersihan badan, kemudian kebersihan pakaian. Hasil wawancara petani tentang PHBS menunjukkan seluruh petani sudah menerapkan PHBS yang baik mulai dari membersihkan tangan dan kuku, lalu membersihkan badan dengan mandi setelah penggunaan pestisida, kemudian membersihkan pakaian yang telah digunakan saat penyemprotan (penggunaan) pestisida. Hal ini sejalan dengan (Safriyanti dkk, 2017) yaitu kebersihan pribadi merupakan salah 
satu pencegahan terhadap penyakit, salah satu tindakan personal hygiene untuk mencegah penyakit yaitu menjaga kebersihan sebelum dan setelah bekerja meliputi (mandi, memakai sabun, memakai handuk, dan pakaian bersih).

Penelitian Herdinanti, (2018) menunjukkan ada hubungan yang bermakna antara personal hygiene dengan gejala keracunan pestisida pada petani nanas di Kecamatan Sungai Gelam Muaro Jambi. Personal hygiene merupakan perawatan diri sendiri yang dilakukan untuk mempertahankan kesehatan baik secara fisik maupun psikologis (Alimul, 2006). Dapat disimpulkan bahwa personal hygiene merupakan kegiatan atau tindakan membersihkan seluruh anggota tubuh yang bertujuan untuk memelihara kebersihan dan kesehatan seseorang.

Keluhan Kesehatan Petani Sayuran di Wilayah Kerja Puskesmas Nusa Indah.

Keluhan kesehatan adalah keadaan seseorang yang mengalami gangguan kesehatan atau kejiwaan, baik karena penyakit akut, penyakit kronis (meskipun selama sebulan terakhir tidak mempunyai keluhan), kecelakaan, kriminal atau lain-lain (Badan Pusat Statistik, 2019). Petani yang mengalami keluhan kesehatan sebanyak 2 orang petani.

Dari hasil wawancara diketahui keluhan kesehatan yang dirasakan oleh 2 orang petani berupa pusing dan mual-mual setelah penggunaan pestisida. Dampak bagi kesehatan manusia tercatat dalam rekaman data yang dikumpulkan Rachel Carson diantaranya: gangguan mual, gangguan hati, syaraf, kelumpuhan (paralysis), gangguan memori, depresi hingga penyakit mental (schizophrennic), kanker, leukemia, anemia aplasik, penyakit Hodgkin's, dan kelainan pada darah. Dari penelitian-penelitian lain diungkap banyak efek negatif bagi kesehatan yang berhubungan dengan pestisida kimia yaitu, terjadinya gangguan pada kulit, gastrointestinal, neurologi, karsinogen, pernafasan, reproduksi, dan gangguan pada endrokrin (Purnomo dkk, 2019).
Studi kasus pernah dilakukan di beberapa negara Asia terhadap pekerja wanita yang bekerja di perkebunan dan berhubungan langsung dengan pestisida, seperti para pekerja yang ada di Malaysia. Hampir setiap hari mereka mengaplikasikan pestisida parakuat, methamidophos, monocrotophos di lahan perkebunan. Akibatnya, para pekerja tersebut mengalami gangguan kesehatan yang kronis dan akut, seperti gatal-gatal, sesak napas, sakit dada, nyeri otot, mata rabun, pusing, mual, dan sakit kanker (Meidiante dkk, 2010).

Penelitian Andriani dan Rosanti, (2018) menunjukkan 18 orang $(60 \%)$ mempunyai tingkat resiko keracunan pestisida, sedangkan kelompok risiko keracunan pestisida dengan kategori rendah sebanyak 1 orang $(3,3 \%)$, dan kelompok risiko keracunan pestisida dengan kategori tinggi sebanyak 11 orang $(36,7)$.

\section{KESIMPULAN}

Petani di wilayah kerja Puskesmas Nusa Indah menggunakan pestisida dalam pengendalian organisme pengganggu tanaman (OPT). Petani belum mempunyai pengetahuan yang baik tentang jenis, dosis, penggunaan pestisida dan belum mengetahui APD lengkap yang harus digunakan saat bekerja.

Petani belum mempunyai sikap yang positif terhadap pestisida, meliputi belum ada tempat penyimpanan khusus, menggunakan jenis dan dosis sesuai keinginannya, merasa aman saat tidak menggunakan APD lengkap.

Tindakan petani dalam penggunaan pestisida menggambarkan masih banyak tindakan yang tidak bijaksana dan dapat membahayakan kesehatan, baik dalam pemilihan, penyimpanan, pencampuran, penyemprotan pestisida, penggunaan APD, dan adanya keluhan kesehatan.

Seluruh petani sudah menerapkan PHBS yang baik mulai dari membersihkan tangan dan kuku, membersihkan badan dengan mandi setelah penggunaan pestisida, membersihkan pakaian yang telah digunakan saat penyemprotan pestisida. 
Keluhan kesehatan yang dirasakan oleh petani meliputi pusing dan mual-mual setelah penggunaan pestisida.

\section{DAFTAR PUSTAKA}

Andraini Yulian dan Eka Rosanti. 2018. Kajian Toksikologi Pestisida Berdasarkan Masa Kerja dan Personal Hygien Pada Petani Hortikultura di Desa Demangan. Ponorogo: Universitas Darussalam Gontor

Azwar, A. 2010. Pengantar Administrasi Kesehatan. Jakarta: Bina Rupa Aksara

Chandra, Budiman. 2007. Pengantar kesehatan lingkungan. Jakarta : ECG

Handayani IGA Rahmi, Edi As'Adi, Guntur Hamzah, Tommy Leonard and Gunarto Gunarto, "Relationship Between Energy Consumption in International Market and Indonesia Prices Regulation", International Journal of Energy Economics and Policy, Vol.7, Issue 5.

Kemenkes RI. 2012. Pedoman Pelaksanaan Teknis STBM. Direktorat Jendral Penyehatan Lingkungan

Kepmenkes RI. 2003. Keputusan Menteri Kesehatan Republik Indonesia No. 942/Menkes/SKVII/2003 tentang Pedoman Persyaratan Hygiene Sanitasi Makanan Jajanan

Mahyuni E L. 2015. Faktor Resiko dalam Penggunaan Pestisida terhadap Keluhan Kesehatan pada Petani di Kecamatan Berastagi Kabupataen Karo. Jurnal KESMAS. Vol 9 No. 1.

Marinda, Dika dan Ardillah, Yustini (2019) Implementasi Penerapatan Sanitasi Tempat-Tempat Umum pada Rekreasi Kuto Besak Kota Palembang. Jurnal Kesehatan Lingkungan Indonesia. Vol. 18 No.2
Notoadmodjo S. 2011. Kesehatan Masyarakat: IImu dan Seni. Jakarta: Rineka Cipta

Permenkes RI. 2014. Peraturan Menteri Kesehatan Indonesia Nomor 3 Tahun 2014 Tentang Sanitasi Total Berbasis Masyarakat

Permenkes. 2016. Peraturan Menteri Kesehatan Republik Indonesia Nomor 43 Tahun 2016 tentang Standar Pelayanan Minimal Bidang Kesehatan

Santoso, I. 2015. Inspeksi Sanitasi Tempattempat Umum. Yogyakarta: Pustaka Baru.

Sapulete, dkk. 2018. Gambaran Konstruksi Sumur Gali dan Jarak Septic Tank terhadap Kandungan Bakteri E-Coli pada Sumur Gali. Jurnal Tunas-Tunas Riset Kesehatan. Vol. 8. No. 1

Sudarmo, S. 1991. Pestisida. Yogyakarta: Kanisius

Sugiarta, Evino., Lindawati. 2018. Hygiene Sanitasi Depot Air Minum. Jurnal Sehat Mandiri. Vol. 13 No. 1

Sulaeman. ES. 2009. Manajemen Kesehatan Teori dan Praktek di Puskesmas. Yogyakarta: Gajah Mada University Press

Tonny dkk. 2015. Modul 3 Penggunaan Pestisida pada Budidaya Cabai Merah, Tomat, Dan Mentimun. Lembang: VegIMPACT

Wandrivel, dkk. 2012. Kualitas Air Minum yang di Produksi Depot Air Minum Isi Ulang di Kecamatan Bungus Padang Berdasarkan Persyaratan Mikrobiologi. Jurnal Kesehatan Andalas. Vol. 1. No. 3

Wudianto. 2001. Petunjuk Pengunaan Pestisida. Jakarta: Penebar Swadaya

Welkriana dan Hasanah. 2020. Gambaran Jumlah Monosit pada Petani Terpapar Pestisida di Desa Keban Agung kabupaten Kepahiang. Jurnal Avicenna Vol 15 No.1. 